\title{
Evaluation of Immunostimulant Activity of Spirulina platensis (Arthrospira platensis) and Sage (Salvia officinalis) in Nile Tilapia (Oreochromis niloticus) \\ Suhair A. Abdellatief ${ }^{1 *}$, Afaf N. Abdel Rahman ${ }^{2}$ and Fatma D.M. Abdallah ${ }^{3}$ \\ ${ }^{1}$ Pharmacology Department, Faculty of Veterinary Medicine, Zagazig University, 44511 Zagazig, Sharkia, Egypt \\ ${ }^{2}$ Fish Diseases and Management Department, Faculty of Veterinary Medicine, Zagazig University, 44511 Zagazig, Sharkia, Egypt \\ ${ }^{3}$ Animal Wealth Development Department, Faculty of Veterinary Medicine, Zagazig University, 44511 Zagazig, Sharkia, Egypt
}

Article History: Received: 11/1/2018 Received in revised form: 5/2/2018 Accepted: 15/2/2018

\begin{abstract}
Immunostimulants have been found to be attractive and promising agents for disease management in aquaculture. The current study aimed to assess the impacts of feeding with Spirulina platensis (SP) and Salvia officinalis (SO) for 28 days on the immune status of Nile tilapia (Oreochromis niloticus). A total of 180 Nile tilapia $(30.6 \pm 0.12 \mathrm{~g})$ were divided into 3 groups (triplicates of $20 \mathrm{fish} /$ group). Control group was fed on a basal diet only, while the other two groups were supplemented with SP (10 gm/ $/ \mathrm{kg}$ diet) and SO (7.5 gm/ $\mathrm{kg}$ diet) respectively. Both of SP and SO showed in vitro antimicrobial activity against Pseudomonas aeruginosa. The immune response of Nile tilapia supplemented with SP and SO revealed significant increases in lysozyme, nitric oxide activities and IgM titer with enhancement of IL-1 $\beta$ and TNF- $\alpha$ genes expression before and after infection with $P$. aeruginosa. Fish challenged with $P$. aeruginosa showed signs of infection with high mortality rate and low relative percentage survival which elevated to be $83 \%$ in SP group and $75 \%$ in SO group. It could be concluded that dietary supplementation with SP and SO improved immune response and protected Nile tilapia against infection. Moreover, SP showed better results than SO before and after infection.
\end{abstract}

Keywords: Spirulina platensis, Salvia officinalis, Nile tilapia, IL-1 $\beta$, TNF- $\alpha$.

\section{Introduction}

Over the most recent three decades, aquaculture represents about $40 \%$ of the global fish production with a reliable growth of $1 \%$ every year. Soon it will be the main source of marine and fresh water sustenance everywhere throughout the world [1-3].

The incidence of microbial pathogens severely affected fish industry [4]. Significant losses have occurred and have subsequently limited aquaculture production in intensive fish culture [5]. Attributable to the wide spread of bacterial resistance to antibiotics, the negative effect on the indigenous microflora of fish and residues of antibiotic which accumulated in fish tissue and environment leading to health hazards in human and animal, the utilization of antibiotics for treatment is not productive and maintainable [6]. Also, the worry of excessive use of antibiotics in aquaculture developed an urgent need to look for an alternative health management strategy, which can be attained by microbial arbitration [7].

The immune-stimulant is defined as a substance which improves the innate or nonspecific immune response by cooperating straightforwardly with cells of the system actuating them. It could be nutritional factors, bacterial preparations, polysaccharides, extracts of animal or plant source, cytokines or chemical agents [8]. In aquaculture, a diversity of substances has been suggested to be used as immune-stimulants including synthetic [9], bacterial [10], animal and plant products [11].

Spirulina platensis (SP), is a cyanobacterium that has been utilized for as long as 20 years as a model organism in numerous investigations for the cultivation of algal biomass to obtain protein and chemicals [12]. It has been built up to be a reasonable natural antioxidant and immune-stimulant to humans and animals with less adverse effects and more cost adequacy than synthetic 
products [13]. Early reports demonstrated the pharmacological activities of $S$. platensis which include antioxidant [14] antiviral [15], antibacterial [16], antiplatelet [17], anticardiotoxic [18], hypocholesterolemic [19], antinephrotoxic [20] and anti-hepatoxic effect [21].

Salvia officinalis (SO) or sage, (Lamiaceae family) is local to the Mediterranean area. The principal constituents of sage leaves are tannic acid, oleic acid, ursonic acid, ursolic acid, niacin, nicotinamide, flavones, flavonoid glycosides, cornsole, cornsolic acid, fumaric acid, chlorogenic acid, caffeic acid, and estrogenic substances [22]. The antioxidant [23], immunomodulatory [24], antimicrobial [25] antinociceptive and anti-inflammatory [26], anticancer [27], antidiabetic [28], antihyperlipidemic [29], diuretic [30], neuroprotective [31], spasmolytic and hypotensive [32] activities of sage have been recorded.

The current study aimed to demonstrate the immune-stimulant effect of $S$. platensis and $S$. officinalis on Nile tilapia before and after infection with Pseudomonas aeruginosa.

\section{Materials and Methods}

\section{S. platensis and S. officinalis}

Pure premium powder of SP was obtained from (HerbaForce, UK). SO leaves were collected from local market, cleaned, shadow dried at $25^{\circ} \mathrm{C}$ then ground to powder.

\section{In vitro screening of antimicrobial activity}

The in vitro antibacterial activity of SP and SO against $P$. aeruginosa was assessed by the method of agar well diffusion [33]. Four ml $0.15 \mathrm{M} \mathrm{NaCl}$ of fresh Pseudomonas

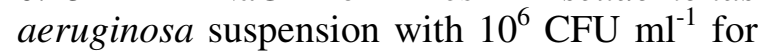
bacteria at OD $620 \mathrm{~nm}$, based on MacFerland's scale were mixed well with 100 $\mathrm{ml}$ melted warm nutrient agar. Wells of $9 \mathrm{~mm}$ diameter were cut in the agar with sterilized cork borer and filled with $100 \mu \mathrm{l}$ of SP or SO with a final concentration of $8 \mathrm{mg} / \mathrm{ml}$ for SP and $10 \mathrm{mg} / \mathrm{ml}$ for SO. To allow the antimicrobial substance to diffuse through the inoculated medium, plates were kept in a refrigerator for 6 hours. After incubation at 30 $\pm 2^{\circ} \mathrm{C}$ for 48 hours, the clearance zones were recorded in $\mathrm{mm}$.

\section{Fish}

Nile tilapia (Oreochromis niloticus) (180 fish) with average body weight of $30.6 \pm 0.12$ $\mathrm{g}$ were got from Fish Research Unit of Faculty of Veterinary Medicine, Zagazig University, Egypt. For acclimation, the fish were kept in glass aquaria $(80 \times 40 \times 30 \mathrm{~cm})$ filled with dechlorinated tap water and fed on basal diet 15 days before beginning of the experiment. Water dissolved oxygen, salinity, temperature, $\mathrm{pH}$, carbonate hardness, ammonia $-\mathrm{N}$, nitrite$\mathrm{N}$ and nitrate- $\mathrm{N}$ were monitored once per week as indicated by APHA [34]. The study was approved by the Committee of Animal Welfare and Research Ethics, Faculty of Veterinary Medicine, Zagazig University, Egypt.

\section{Diets and experimental design}

The commercial ingredients used for formulation of fish basal diet and its chemical analysis were showed in Table 1. The fish were arbitrarily partitioned into 3 equal experimental groups (triplicates of 20 fish/ each group). Control group was nourished on a basal diet only, while the other two groups were supplemented with diets contained SP (10 gm/ $\mathrm{kg}$ diet) [35] and SO (7.5 gm/ $/ \mathrm{kg}$ diet) [36] respectively. The diets were supplied at the rate of $2 \%$ of the fish biomass twice daily for 28 days and adjusted every two weeks according to fish weight. 
Table 1: Basal diet composition and its chemical analysis

\begin{tabular}{ll}
\hline Ingredients & Percentage of diet \\
\hline Fish meal & 25 \\
Soy bean meal & 22 \\
Ground yellow corn & 26.5 \\
Meat meal & 20 \\
Fish oil & 5 \\
Vitamin and mineral mixture (premix) & 1.5 \\
Calculated chemical analysis & \\
Crude protein & 39.9 \\
Crude lipid & 10.89 \\
Crude fiber & 3.68 \\
Moisture & 10.58 \\
Ash & 9.11 \\
\hline
\end{tabular}

\section{Sampling}

Blood was gathered from (five fish/group) from the caudal veins at the $2^{\text {nd }}$ and the $4^{\text {th }}$ weeks of the experiment to be centrifuged at $3000 \mathrm{rpm} / 15 \mathrm{~min}$ to get clear serum which was kept at $-20{ }^{\circ} \mathrm{C}$ till be used.

Head kidney tissues were collected from 5 fish/group at the $2^{\text {nd }}$ and the $4^{\text {th }}$ weeks of the experiment to be used for detection of gene expression.

\section{Non-specific and specific immune assays}

Serum lysozyme activity was detected using the method of Ellis [37], serum nitric oxide (NO) was determined according to Rajaraman [38]. The level of immunoglobulin (IgM) was measured in serum according to Siwicki and Anderson [39].

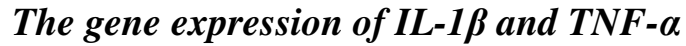

Extraction of Total RNA from the head kidney tissue was applied utilizing RNeasy Mini Kit, (QIAGEN, Germany) following the manufacturer's instructions. The yields and purity of Total RNA were detected by using Spectrophotometer 260 and $280 \mathrm{~nm}$ absorbance (Thermo Scientific, USA). RevertAid Reverse Transcriptase kit (Thermo Fisher) and oligo-dT were utilized for cDNA synthesis. Initial heat denaturation $\left(65^{\circ} \mathrm{C}\right.$ for $\left.5 \mathrm{~min}\right)$ was performed for $1 \mu \mathrm{g}$ of total RNA, then $20 \mu \mathrm{l}$ of the reactions were incubated at $42^{\circ} \mathrm{C} / 1 \mathrm{~h}$ and then at $85^{\circ} \mathrm{C} / 15$ min. After that, cDNA was added to a SYBR Green qPCR Master Mix (QIAGEN, Germany) containing $30 \mathrm{pg} / \mathrm{ml}$ of primer pairs specific for target genes, [40,41] (Table 2) designed by the Primer 3 program. Initial denaturation was done at $95^{\circ} \mathrm{C} / 1 \mathrm{~min}$, then 40 cycles were utilized for denaturation at $95^{\circ} \mathrm{C} /$ $15 \mathrm{~s}$, annealing at $57^{\circ} \mathrm{C} / 20 \mathrm{~s}$ and extension at $72^{\circ} \mathrm{C} / 45 \mathrm{~s}$. The extent of all amplicons was affirmed on $2 \%$ agarose gel electrophoresis stained with SYBR Safe DNA gel stain (Invitrogen). The reference gene utilized was EF-1 $\alpha$ [42]. The calculation of the levels of gene expression levels was performed according to Schmittgen and Livak [43].

Table 2: Oligonucleotide primers and probes used in SYBR Green real time PCR

\begin{tabular}{lll}
\hline Gene & \multicolumn{1}{c}{$\begin{array}{c}\text { Primer sequence } \\
\left(\mathbf{5}^{\prime} \mathbf{- 3} \mathbf{\prime}\right)\end{array}$} & \multicolumn{1}{c}{ Reference } \\
\hline IL-1B & GCTGGAGAGTGCTGTGGAAGACATATAG & Castro et al. [40] \\
TNF alpha & CCTGGAGCATCATGGCGTG & Standen et al. $[$ [41] \\
& CCAGAAGCACTAAAGGCGAAGA & Gröner et al. $[42]$ \\
EF-1 $\alpha$ & CCTTGGCTTTGCTGCTGATC & \\
& CCTTCAACGCTCAGGTCATC & \\
\hline
\end{tabular}




\section{Challenge test}

After the 28 day feeding experiment, 30 fish from each treatment were challenged intraperiotneally with $0.2 \mathrm{ml}$ of $1 \times 10^{7} \mathrm{cfu}$ of $P$. aeruginosa (previously isolated at the Department of Fish Diseases and Management, Faculty of Veterinary Medicine, Zagazig University under project No.5589 from moribund fish and confirmed to be pathogenic). The challenged fish were observed for 14 days to determine the clinical signs, post-mortem findings and the mortality rates. The moribund fish were used for bacterial re-isolation. Recorded mortalities were utilized to estimate the relative percentage survival (RPS) as following:

RPS $=100-[$ (treatment mortality/ control mortality) x 100] [44].

Three days after infection, blood samples were collected to get serum which used for estimation of the same immunity indices and head kidney tissues were obtained from 3 fish in each treatment to be used for estimation of the genes expression of IL- $1 \beta$ and TNF- $\alpha$.

\section{Statistical analysis}

The statistical analysis was applied by using the SPSS (21) package program. Duncan's Multiple Range Test was utilized to detect the statistical differences between groups. Values were expressed as means \pm standard error. Differences with $\mathrm{p}<0.05$ were considered significant.

\section{Results}

\section{In vitro antimicrobial activity}

The inhibition zones of SP and SO against Pseudomonas aeruginosa were 11 and $10 \mathrm{~mm}$ respectively.

\section{Non-specific and specific immune assays}

The effects of supplementation with SP and SO on the non-specific and specific immune parameters of Nile tilapia are shown in Table, 3 . At the end of the second and the fourth week of feeding trials, the lysozyme activities, nitric oxide assay and the titer of IgM showed a significant increase in SP and SO groups when compared with the control group. That increase noted after 2 and 4 weeks of supplementation was significant in SP group when correlated with SO group.

Supplementation of Nile tilapia infected with $P$. aeruginosa with SP and SO resulted in a significant increase in the lysozyme activities, nitric oxide assay and the titer of $\operatorname{IgM}$ when contrasted with the control infected group. That increase was significant in SP group than SO group, (Table, 3).

Table 3: Effect of supplementation with Spirulina platensis $(10 \mathrm{gm} / \mathrm{kg}$ diet $)$ and Salvia officinalis $(7.5 \mathrm{gm} / \mathrm{kg}$ diet) for 28 days on lysozymes, nitric oxide activities and IgM level in Nile tilapia before and after infection with pseudomonas aeruginosa.

\begin{tabular}{|c|c|c|c|c|}
\hline Time & $\begin{array}{ll}\text { Groups } & \text { Parameters }\end{array}$ & Lysozymes & Nitric oxide & $\operatorname{lgM}$ \\
\hline \multirow[t]{3}{*}{$2^{\text {nd }}$ week } & control & $0.243 \pm 0.001^{\mathrm{c}}$ & $43.400 \pm .510^{\mathrm{c}}$ & $0.166 \pm 0.008^{\mathrm{c}}$ \\
\hline & $\mathrm{sp}$ & $1.073 \pm 0.013^{\mathrm{a}}$ & $59.600 \pm .510^{\mathrm{a}}$ & $0.972 \pm 0.001^{\mathrm{a}}$ \\
\hline & so & $0.617 \pm 0.001^{\mathrm{b}}$ & $55.00 \pm .707^{\mathrm{b}}$ & $0.588 \pm 0.001^{\mathrm{b}}$ \\
\hline \multirow[t]{3}{*}{$4^{\text {th }}$ week } & control & $0.327 \pm 0.007^{\mathrm{c}}$ & $46.60 \pm 0.510^{c}$ & $0.254 \pm 0.001^{\mathrm{c}}$ \\
\hline & $\mathrm{sp}$ & $1.693 \pm 0.001^{\mathrm{a}}$ & $66.60 \pm 0.510^{\mathrm{a}}$ & $1.552 \pm 0.001^{\mathrm{a}}$ \\
\hline & so & $1.213 \pm 0.001^{\mathrm{b}}$ & $61.40 \pm 0.510^{b}$ & $1.176 \pm 0.001^{\mathrm{b}}$ \\
\hline \multirow[t]{3}{*}{ Post infection } & infected control & $0.969 \pm 0.001^{\mathrm{c}}$ & $56.60 \pm 0.510^{c}$ & $0.859 \pm 0.001^{\mathrm{c}}$ \\
\hline & $\mathrm{sp}$ & $2.569 \pm 0.001^{\mathrm{a}}$ & $73.60 \pm 0.510^{\mathrm{a}}$ & $2.440 \pm 0.001^{\mathrm{a}}$ \\
\hline & so & $2.153 \pm 0.001^{\mathrm{b}}$ & $68.60 \pm 0.510^{\mathrm{b}}$ & $2.023 \pm 0.001^{\mathrm{b}}$ \\
\hline
\end{tabular}

Values are represented as Mean \pm SE (n=5/group). Means within the same column carrying different superscripts are significant at $(\mathrm{p}<0.05)$. 


\section{The IL-1ß and TNF- $\alpha$ genes expression}

As demonstrated in table, 4 , the expression of IL- $1 \beta$ and TNF- $\alpha$ genes was enhanced in groups received SP and SO when compared with control group at the end of the second and the fourth week of feeding. That effect was significant in SP group than SO group.

Groups of SP and SO showed a significant increase in IL- $1 \beta$ and TNF- $\alpha$ genes expression when compared with control infected group. That increase was significant in SP group than SO group, (Table, 4).

Table 4: Effect of supplementation with Spirulina platensis $(10 \mathrm{gm} / \mathrm{kg}$ diet $)$ and Salvia officinalis $(7.5 \mathrm{gm} / \mathrm{kg}$ diet) for 28 days on IL-1ß and TNF- $\alpha$ genes expression in Nile tilapia before and after infection with pseudomonas aeruginosa.

\begin{tabular}{|c|c|c|c|}
\hline Time & Parameters & Il-1及 & TNF- $\alpha$ \\
\hline \multirow[t]{3}{*}{$2^{\text {nd }}$ week } & control & $1.808 \pm 0.055^{\mathrm{c}}$ & $2.114 \pm 0.055^{\mathrm{c}}$ \\
\hline & sp & $5.496 \pm 0.052^{\mathrm{a}}$ & $5.806 \pm 0.052^{\mathrm{a}}$ \\
\hline & so & $3.618 \pm 0.055^{\mathrm{b}}$ & $3.928 \pm 0.055^{\mathrm{b}}$ \\
\hline \multirow[t]{3}{*}{$4^{\text {th }}$ week } & control & $1.908 \pm 0.055^{\mathrm{c}}$ & $2.198 \pm 0.051^{\mathrm{c}}$ \\
\hline & $\mathrm{sp}$ & $6.442 \pm 0.053^{\mathrm{a}}$ & $6.742 \pm 0.053^{\mathrm{a}}$ \\
\hline & so & $4.698 \pm 0.055^{\mathrm{b}}$ & $5.008 \pm 0.055^{\mathrm{b}}$ \\
\hline \multirow[t]{3}{*}{ Post infection } & infected control & $.788 \pm 0.009^{c}$ & $1.0880 \pm 0.009^{c}$ \\
\hline & $\mathrm{sp}$ & $5.662 \pm 0.053^{\mathrm{a}}$ & $5.7720 \pm 0.167^{\mathrm{a}}$ \\
\hline & so & $4.494 \pm 0.050^{\mathrm{b}}$ & $4.8040 \pm 0.050^{\mathrm{b}}$ \\
\hline
\end{tabular}

Values are represented as Mean $\pm \mathrm{SE}$ ( $\mathrm{n}=5$ /group). Means within the same column carrying different superscripts are significant at $(\mathrm{p}<0.05)$.

\section{Clinical and post-mortem findings}

Fish challenged with $P$. aeruginosa showed petechial hemorrhages and ulceration on body surface, especially at the base of fins, tail and fins rot, congested gills and abdominal distention. Internally, abdominal dropsy with congestion of internal organs was observed. Mortality rates were $17 \%$ SP group and $25 \%$ in SO group compared with $75 \%$ for the control group. The relative percentage survival (RPS) was $83 \%$ and $75 \%$ in SP and SO groups respectively.

\section{Discussion}

Spirulina is viewed as a standout amongst the most generally utilized microalgal species in aquaculture because of its high constituents of protein, essential amino acids, antioxidant pigments, essential fatty acids, carotenoids, vitamins and minerals [45].

The antimicrobial activity of SP may be attributed to its constituents from antimicrobially active lipids and fatty acids
[46]. It was suggested that lipids kill microorganisms by disruption of their cell membrane [47]. The antimicrobial activity of SP observed in the current study against $P$. aeruginosa was in agreement with early observations recorded by Sudha et al. [48] and Pradhan et al. [49].

Salvia officinalis is cultivated in numerous countries for its dried leaves which are used as raw material in medicine, food-industry and perfumery [50]. It has been found that the essential oil and leaves extracts of SO have a wide range of antimicrobial effects which may be due to its particular chemical constituents [51]. The present observations revealed that the leaves of SO prevented $P$. aeruginosa. Similar findings previously reported [52].

In comparison to mammals, fish for the most part depend on innate immunity [53]. As needs be, awesome great consideration has been centered on the utilization of dietary bioactive materials to fortify innate immunity. 
In fish, lysozyme is an essential antimicrobial effector that fills in as an opsonin in complement system and phagocytes initiation [54,55]. It is recognized in the blood, mucus and organs of different fish and assumes a critical bactericidal part in the non specific defense against pathogens primarily through lytic effects on their cell membrane. By splitting glycosidic bonds between $\mathrm{N}$ acetylmuramic acid and Nacetylglucosamine, it hydrolyzes the peptidoglycan layers of bacterial cell membranes [56].

Nitric oxide (NO) is bactericidal reactive oxygen that is delivered fundamentally by macrophages after incitement with an assortment of operators, for example, microbial segments and cytokines [57, 58].

In the current study, it has been observed that Nile tilapia fed on diets supplemented with SP and SO showed a significant enhancement in the lysozyme activity and a significant increase in the level of NO. The immune-modulatory activity of SP especially, associated with non-specific immune system has been suggested [59,60]. That effect was attributed to its content of C-phycocyanin which increased the phagocytic and the natural killer activities [61]. Our results were similar to those early observed that SP enhanced the immune response in channel catfish [59] and Nile tilapia [62].

Water soluble polysaccharide as galactose, glucose, mannose, xylose, and fructose are active SO compounds that have been found to possess immune modulatory activity [63], including anti-inflammatory, anti-cancer, antiulcer, macrophage phagocytic stimulation and induction of cytokine as well as complement activating potency [64]. In concurrence with our findings, previous reports suggested that supplementation with SO augmented immunity in rainbow trout [65].

Antibodies (immunoglobulins) are glycoproteins that expressed in the membrane of the B lymphocyte (BCR) or free in body fluids, secreted by plasma cells (B lymphocytes activated by antigen connection) [66]. The predominant immunoglobulin in teleosts is a tetramer of the $\operatorname{IgM}$ class and contains eight antigenic combining sites [67]. Some teleosts have a monomer of IgM in their serum, although the factors leading to its expression are still unknown [68].

Our findings revealed that addition of SP and SO in the diet of Nile tilapia elevated the level of serum IgM. Those findings are in the same direction with those noted after SP [69] and SO [70] supplementation.

As a member of interleukin-1 (IL-1) cytokine family, Interleukin-1 $\beta$ (IL-1 $\beta$ ), is a prototypical pro-inflammatory cytokine and key mediator of the body's reaction to microbial infection, immunological response and tissue damage [71].

TNF- $\alpha$, a pro-inflammatory cytokine, is one of the early immune genes expressed at the beginning of infection in fish and has a key part in controlling inflammation. In fish, TNF$\alpha$ shows overlapping functions with IL- $1 \beta$. Numerous fish TNF- $\alpha$ s have been generated in bacteria as monomers, dimers and trimers and can enact macrophages/phagocytes and improve their killing activity against microorganisms [72].

Our findings showed a significant increase in the expression of IL- $1 \beta$ and TNF- $\alpha$ of Nile tilapia fed on SP and SO. Early studies recorded similar observations on SP [60, 69] and SO [73].

Concerning the effect of supplementation with SP and SO in Nile tilapia after infection with $p$. aeruginosa, the current data revealed that addition of SP and SO elicited a significant elevation in lysozyme activity, NO level and IgM titer. In addition, the expression of pro-inflammatory cytokine (IL-1 $\beta$ and TNF- $\alpha$ ) was up-regulated. Those findings indicated the ability of those supplementations to protect Nile tilapia against infection with $P$. aeruginosa. Our findings are consistent with those early observed by Abu-Elala et al. [74]; Mahmoud et al., [75] on SP and Velickovic et al. [52] on SO.

Fish challenged with $P$. aeruginosa showed petechial hemorrhages and ulceration on body surface, especially at the base of fins, tail and fins rot, congested gills and abdominal distention. Internally, abdominal dropsy with congestion of internal organs was observed. These lesions could be attributed to the different types of toxins produced by $P$. aeruginosa [76]. Likewise, Eissa et al. [77] 
noted irregular hemorrhages on body surface, cloudiness of eyes, scales detachment and congested gills, In addition to, sanguineous fluids in the abdominal cavity as signs of pseudomoniasis in Oreochromis niloticus.

Mortality rates were $17 \%$ in SP group and $25 \%$ in SO group compared with $75 \%$ for control group. The relative percentage survival (RPS) was $83 \%$ in SP group and $75 \%$ in SO group. The decline in mortality rate in groups supplemented with SP and SO may indicate their activity against pseudomonas infection.

\section{Conclusion}

Based on the findings of present study, it could be concluded that both of SP and SO has an immunostimulant effect and are recommended to be used as feed additives in Nile tilapia.

\section{Conflict of interest}

The authors declare that they have no conflict of interest.

\section{References}

[1] Food and Agriculture Organization of the United Nations (FAO) (2007): The State of World. Fisheries and Aquaculture. Rome: FAO Fisheries and Aquaculture Department.

[2] Davila, J.; Marcial_Martinez, ML.; Viana, MT. and Vazquez_Duhal, R.(2010): The effect of broccoli in diet on the cytochrome $\mathrm{P} 450$ activities of tilapia fish (Oreochromis niloticus) during phenol exposure. Aquaculture, 304: 58-65.

[3] Almeida, IFM.; Martins, HML.; Santos, SMO.; Freitas, MS.; da Costa, JM. and D'Almeida Bernardo, FM.(2011): Mycobiota and aflatoxin B1 in feed for farmed sea bass (Dicentrarchus labrax). Toxins, 3:163-171.

[4] Zorrilla, I.; Chabrill_on, M.; Arijo, S.; Diaz-Rosales, P.; Martınez-Manzanares, E.; Balebona, M. et al. (2003): Bacteria recovered from diseased cultured gilthead sea bream (Sparus aurata L.) in southwestern Spain. Aquaculture, 218: 11-20.

[5] Subasinghe, RP. (2005): Epidemiological approach to aquatic animal health management: opportunities and challenges for developing countries to increase aquatic production through aquaculture. Prev Vet Med, 67: 117-124.

[6] Misra, CK.; Das, BK.; Mukherjee, SC. and Pattnaik, P. (2006): Effect of multiple injections of Beta-glucan on non-specific immune response and disease resistance in Labeorohita fingerlings. Fish Shellfish Immunol, 20: 305-319.

[7] Panigrahi, A. and Azad, IS. (2007): Microbial intervention for better fish health in aquaculture: The Indian scenario. Fish Physiology and Biochemistry, 33: 429 - 440.

[8] Sakai, M. (1999): Current research status of fish immunostimulants. Aquaculture, 172: 63-92.

[9] Rao, YV.; Das, BK.; Pradhan, J. and Chakrabarti, R.(2006): Effect of Achyranthes aspera on the immunity and survival of Labeo rohita infected with Aeromonas hydrophila. Fish Shellfish Immunol, 20: 263-273.

[10] Goetz, FW.; Lliev, DB.; McCauley, LAR.; Liarte, CQ.; Tort, LB.; Planas, JV. and Mackenzie, S. (2004): Analysis of genes isolated from lipopolysaccharide stimulated rainbow trout (Oncorhynchus mykiss) macrophages. Mol Immunol, 41:1199-1210.

[11] Ardo, L.; Yin, G.; Xu, P.; Varadi, L.; Zigeti, GS.; Jeney, Z. and Jeney, G. (2008): Chinese herbs (Astragalus membranaceus and Lonicera japonica) and boron enhance the non-specific immune response of Nile tilapia (Oreochromis niloticus) and resistance against Aeromonas hydrophila. Aquaculture, 275: 26-33.

[12]Chen, F. and Zhang, Y. (1997): High cell density mixotrophic culture of Spirulina platensis on glucose for phycocyanin production using a fed-batch system. Enzyme Microbiol Technol, 20: 221224.

[13] Belay, A. (2002): The potential application of Spirulina (Arthrospira) as a nutritional and therapeutic supplement 
in health management, Review. J. Am. Nutraceut. Assoc, 5: 27-48.

[14] Dartsch, PC. (2008): Antioxidant potential of selected Spirulina platensis preparations. Phytotherapy Research, 22: 627-633.

[15] Hernandez-Corona, A.; Nieves, I.; Meckes, M.; Chamorro, G. and Barron, BL. (2002): Antiviral activity of Spirulina maxima against herpes simplex virus type 2. Antiviral Res, 56: 279-285.

[16] Özdemir, G.; Karabay, NU.; Dalay, MC. and Pazarbasi, B. (2004): Antibacterial activity of volatile component and various extracts of Spirulina platensis. Phytother Res, 18: 754-757.

[17] Hsiao, G.; Chou, PH.; Shen, MY.; Chou, DS.; Lin, CH. and Sheu, JR. (2005): Cphycocyanin, a very potent and novel platelet aggregation inhibitor from Spirulina platensis. J Agric Food Chem, 53: 7734-7740.

[18] Khan, M.; Shobha, JC.; Mohan, IK.; Naidu, MUR.; Sundaram, C.; Singh, S. et al. (2005): Protective effect of Spirulina against doxorubicin-induced cardiotoxicity. Phytother Res, 19: 10301037.

[19] Nagaoka, S.; Shimizu, K.; Kaneko, H.; Shibayama, F.; Morikawa, K.; Kanamaru, Y. et al. (2005): A novel protein Cphcocyanin plays a crucial role in the Hypocholesterolemic action of Spirulina platensis concentrate in rats. J Nutr, 135: 2425-2430.

[20] Khan, M.; Shobha, JC.; Mohan, IK.; Naidu, MUR.; Prayag, A. and Kutala, VK. (2006): Spirulina attenuates cyclosporine-induced nephrotoxicity in rats. J Appl Toxico, 26: 444-451.

[21] Mohan, IK.; Khan, M.; Shobha, JC.; Naidu, MUR.; Prayag, A.; Kuppusamy, P. et al. (2006): Protection against cisplatininduced nephrotoxicity by Spirulina in rats. Cancer Chemother Pharmacol, 58: 802-808.

[22] Akhondzadeh, S.; Noroozian, M.; Mohammadi, M.; Ohadinia, S.; Jamshidi, AH. and Khani M. (2003): Salvia officinalis extract in the treatment of patients with mild to moderate Alzheimer's disease: a double blind, randomized and placebo-controlled trial. J Clin Pharm Ther, 28: 53-9.

[23] Anamaria, P.; Muste, S.; Mureşan, C.; Pop, C. and Salanţă, L. (2013): Comparative study regarding the importance of sage (Salvia officinalis L.) in terms of antioxidant capacity and antimicrobial activities. Hop Med. Plants, 1(2): 41-42.

[24] Capek, P.; Hribalova, V.; Svandova, E.; Ebringerova, A.; Sasinkova, V. and Masarova, J. (2003): Characterization of immunomodulatory polysaccharides from Salvia officinalis L. International Journal of Biological Macromolecules, 33, 113- 119.

[25] Weckesser, S.; Engel, K.; Simon Haarhaus, B.; Wittmer, A.; Pelz, K. and Schempp, CM. (2007): Screening of plant extracts for antimicrobial activity against bacteria and yeasts with dermatological relevance. Phytomedicine, 14: 508-516.

[26] Rodrigues, MR.; Kanazawa, LK.; das Neves, TL.; da Silva, CF.; Horst, H.; Pizzolatti, MG.; Santos, AR.; Baggio, $\mathrm{CH}$. and Werner, MF. (2012): Antinociceptive and anti-inflammatory potential of extract and isolated compounds from the leaves of Salvia officinalis in mice. J. Ethnopharmacol, 139 (2): 519-526.

[27] Russo, A.; Formisano, C.; Rigano, D.; Senatore, F.; Delfine, S.; Cardile, V.; Rosselli, S. and Bruno, M. (2013): Chemical composition and anticancer activity of essential oils of Mediterranean sage (Salvia officinalis L.) grown in different environmental conditions. Food Chem. Toxicol, 55: 42-47.

[28] Hajzadeh, MAR.; Rajaei, Z.; Ghamami, G. and Tamiz, A. (2011): The effect of Salvia officinalis leaf extract on blood glucose in streptozotocin - diabetic rats. Pharmacol. Online, 1: 213 - 220.

[29] Ninomiya, K.; Matsuda, H.; Shimoda, H.; Norihisa, N.; Kasajima, N.; Yoshino, 
T.; Morikawa, T. and Yoshikawa, M. (2004): Carnosic acid, a new class of lipid absorption inhibitor from sage. Bioorganic \& Medicinal Chemistry Letters, 14: 1943-1946.

[30] Bhadoriya, U.; Tiwari, S.; Sharma, P.; Bankey, S. and Mourya, M. (2011): Diuretic activity of extract of Salvia officinalis. Asian J. Pharm. Life Sci, 1 (1): 24-28.

[31] Luvone, T.; DeFilippis, D.; Esposito, G.; D'Amico, A. and Izzo, A. (2006): The spice sage and its active ingredient rosmarinic acid protect $\mathrm{PC} 12$ cells from amyloid-beta peptide-induced neurotoxicity. J Pharmacol Exp Ther, 317: 1143-1149.

[32] Todorov, S.; Philianos, S.; Petkov, V.; Harvala, C.; Zamfirova, R. and Olimpiou, H.(1984): Experimental pharmacological study of three species from genus Salvia. Acta Physiologica et Pharmacologica Bulgarica, 10, 13-20.

[33] Perez, C.; Pauli, M. and Bazerque, P. (1990): An antibiotic assay by agar-well diffusion method. Acta Biologiae et Medecine Experimentalis, 15: 113-115.

[34] APHA. (1998): Standards Methods for Examination of Water and Wastewater, $20^{\text {th }}$ ed., (American Health Association) American Public Health Association Inc, Washington DC.

[35] Ibrahem, M. D.; Mohamed, M. F. and Ibrahim, M. A. (2013): The Role of Spirulina platensis (Arthrospira platensis) in Growth and Immunity of Nile Tilapia (Oreochromis niloticus) and Its Resistance to Bacterial Infection. Journal of Agricultural Science, 5 (6): 109-117.

[36] El-Gendy, M. O.; El-Komy, H. M. A.; Shehab El-Din, M. T. E.; Tolan, A. E. and Salem, M.F.I. (2010): Effect of some medicinal plants on growth parameters and health status of Nile Tilapia (Oreochromis niloticus). J. of Animal and Poultry Production, 1(1): 11 -22 .

[37] Ellis, AE. (1990): Lysozyme assays. Tech fish Immunol, 1: 101-103.
[38] Rajaraman, V.; Nonnecke, B; Franklin, S.; Hammell, D. and Horst, R. (1998): Effect of vitamins $\mathrm{A}$ and $\mathrm{E}$ on nitric oxide production by blood mononuclear leukocytes from neonatal calves fed milk replacer 1, 2, 3. J Dairy Sci, 81: 32783285 .

[39] Siwicki, AK. and Anderson, DP. (1993): Immunostimulation in fish: Measuring the effects of stimulants by serological and immunological methods. Nordic Symposium on Fish Immunology, Lysekil, Sweden.

[40]Gröner, F.; Ziková, A. and Kloas, W. (2015): Effects of the pharmaceuticals diclofenac and metoprolol on gene expression levels of enzymes of biotransformation, excretion pathways and estrogenicity in primary hepatocytes of Nile tilapia (Oreochromis niloticus). Comparative Biochemistry and Physiology, Part C 167: 51-57.

[41]Castro, R.; Zou, J.; Secombes, C.J. and Martin, S.A.M. (2011): Cortisol modulates the induction of inflammatory gene expression in a rainbow trout macrophage cell line. Fish \& Shellfish Immunology, 30: 215-223.

[42]Standen, B.T.; Peggs, D.L.; Rawling, M.D.; Foey, A.; Davies, S.J.; Santos, G.A. and Merrifield, D.L. (2016): Dietary administration of a commercial mixed-species probiotic improves growth performance and modulates the intestinal immunity of tilapia, Oreochromis niloticus. Fish \& Shellfish Immunology, 49: 427-435.

[43]Schmittgen, TD. and Livak, KJ. (2008): Analyzing real-time PCR data by the comparative CT method. Nat Protoc, 3: 1101-1108.

[44] Amend, DF. (1981): Potency Testing of Fish Vaccines. Fish biologics: serodiagnostics and vaccines.

[45] Nakagawa, H. and Montgomery, WL. (2007): Algae. In: Dietary Supplements for the Health and Quality of Cultured Fish. Nakagawa H, Sato $M$ and Gatlin DM 3rd, eds. CABI International, Cambridge,MA, US, pp. 133-168. 
[46] Xue, C.; Hu, Y.; Saito, H.; Zhang, Z.; Li, Z.; Cai,Y. et al. (2002): Molecular species composition of glycolipids from Spirulina platensis. Food Chemistry, 77: 9-13.

[47] Bergsson, G. (2005): Antimicrobial polypeptides and lipids as a part of innate defence mechanism of fish and human fetus. A thesis, Karoliska Institute, Stockholm.

[48] Sudha, SS.; Karthic, R.; Rengaramunjan, J. and Athulya, A. (2011): Antimicrobial activity of Spirulina platensis and Aphanothece sp. on selected clinical bacterial isolates and its antioxidant activity. South As. J. Biol. Sci, 1: 87-98.

[49] Pradhan, J.; Das, BK.; Sahu, S.; Marhual, NM.; Swain, AK.; Mishra, BK.et al. (2012): Traditional antibacterial activity of freshwater microalga Spirulina platensis to aquatic pathogens. Aqua. Res. 43 (9): 1287-1295.

[50] Bruneton, J. (1999): "Pharmacognosy, Phytochemistry, Medicinal Plants". Second ed., Lavoisier Publishing, Paris, pp. 540-544.

[51] Mossi, AJ.; Cansian, RL.; Paroul, N.; Toniazzo, G.; Oliveira, JV. and Pierozan, MK. (2011): Morphological characterisation and agronomical parameters of different species of Salvia sp. (Lamiaceae). Braz J. Biol, 71: 121129.

[52] Velickovic, D.; Randjelovic, N. and Ristic, M. (2003): Chemical constituents and antimicrobial activity of the ethanol extracts obtained from the flower, leaf and stem of Salvia officinalis L. J Serb Chem, 68(1): 17-24.

[53] Swain, P.; Dash, S.; Sahoo, PK.; Routray, P.; Sahoo, SK; Gupta, SD.; Meher, PK. and Sarangi, N. (2007): Nonspecific immune parameters of brood Indian major carp Labeo rohita and their seasonal variations. Fish Shellfish Immunol, 22: 38-43.

[54] Magnadottir, B. (2006): Innate immunity of fish (overview). Fish Shellfish Immunol, 20: 137-151.
[55] Yeh, P.; Chang, CA.; Chang, CY.; Liu, CH. and Cheng, W. (2008): Dietary Sodium Alginate Administration Affects Fingerling Growth and Resistance to Streptococcus sp. and Iridovirus, and Juvenile Non-specific Immune Responses of the Orange-Spotted Grouper, Epinephelus coioides. Fish Shellfish Immunology, 25: 19-27.

[56] Lindsay, GJ. (1986): The significance of chitinolytic enzymes and lysozyme in rainbow trout $\mathrm{G}$ (Salmo gairdneri) defence, Aquaculture, 51: 169-173.

[57] Gomez-Gil, B.; Roque, A. and Turnbull, JF. (2000): The use and selection of probiotic bacteria for use in the culture of larval aquatic organisms. Aquaculture, 191: 259-270.

[58]Campos-Perez, JJ. ; Ellis, AE. and Secombes, CJ. (2000): Toxicity of nitric oxide and peroxynitrite to bacterial pathogens of fish, Dis Aquat Organ, 43: 109-115.

[59] Duncan, LP. and Klesius, PH. (1996): Effect of feeding spirulina on specific and non-specific immune responses of Channel catfish. Journal of Aquatic Animal Health, 8: 308-313.

[60] Watanuki, H.; Kazuki, O.; Malina, AC.; Tassakka, AR.; Toshimitsu, K. and Sakai, M. (2006): Immunostimulant effects of dietary Spirulina platensis on carp, Cyprinus carpio. Aquaculture, 258: 157- 163.

[61] Qureshi, MA. and Ali, RA. (1996): Spirulina platensis exposure enhances macrophage phagocytic function in cats. Immunopharmacology and Immuno toxicology, 18: 457-463.

[62] Ragap, HM.; Khalil, RH. and Mutawie, HH. (2012): Immunostimulant effects of dietary Spirulina platensis on tilapia Oreochromis niloticus. Journal of Applied Pharmaceutical Science, 2 (2): 26-31.

[63] Capek, P. and Hribalova, V. (2004): Water-Soluble polysaccharides from Salvia officinalis L. possessing immunomodulatory activity. Phytochemistry, 65: 1983-1992. 
[64] Ebringerova, A.; Kardosova, A.; Hromadkova, Z. and Hriblova, V. (2003): Mitogenic and comitogenic activities of polysaccharides from some European herbaceous plants. Fitoterpia, 74: 52- 61.

[65] Terzioğlu, S. and Diler, Ö. (2016): Effect of Dietary Sage (Salvia officinalis L.), Licorice Root (Glycyrrhize glabra L.), Blueberry (Vaccinium myrtillus L.) and Echinaceae (Echinacea angustifolia Hell) on Nonspecific Immunity and Resistance to Vibrio anguillarum Infection in Rainbow Trout, (Oncorhynchus mykiss). Süleyman Demirel Üniversitesi Eğirdir Su Ürünleri Fakültesi Dergisi, 12(2): 110-118.

[66] Goldsby, RA.; Kindt, TJ.; Osborne, BA. and Kuby, J. (2002): In: Immunology, 5th ed., WH Freeman \& Company Publisher, $554 \mathrm{p}$.

[67] Acton, RT.; Weinheimer, PF.; Hall, SJ.; Niedermeier, W.; Shelton, E. and Bennett, JC. (1971): Tetrameric immune macroglobulins in three orders of bony fishes. Proceedings of the National Academy of Sciences of the United States of America, 68: 107-111.

[68] Wilson, MR. and Warr, GW. (1992): Fish immunoglobulins and the genes that encode them. Annual Review of Fish Disease, 2: 201-221.

[69] Khalil, SR.; Reda, RM. and Awad, A.(2017): Efficacy of Spirulina platensis diet supplements on disease resistance and immune-related gene expression in Cyprinus carpio L. exposed to herbicide atrazine. Fish Shellfish Immunol, 67: 119-128.

[70] Khudiar, KK. and Hussein, GJ. (2017): Effect of alcoholic extract of Salvia officinalis leaves on some physiological parameters aspects in acrylamide-treated rats. Adv. Anim. Vet. Sci, 5(1): 47-55.

[71] Husain, M.; Bird, S.; van Zwieten, R.; Secombes, C.J. and Wang, T. (2012): Cloning of the IL-1_3 gene and IL-1_4 pseudogene in salmonids uncovers a second type of IL-1_ gene in teleost fish. Dev. Comp. Immunol, 38: 431-446.

[72] Zhang, A.; Chen, D.; Wei, H.; Du, L.; Zhao, T.; Wang, X. and Zhou, H. (2012): Functional characterization of TNF- $\alpha$ in grass carp head kidney leukocytes: Induction and involvement in the regulation of NF-_B signaling. Fish Shellfish Immunol, 33: 1123-1132.

[73] Radtkea, OA.; Foob, LY.; Lub, Y.; Kiderlenc, AF. and Kolodzieja, $\mathrm{H}$. (2003): Evaluation of Sage Phenolics for Their Antileishmanial Activity and Modulatory Effects on Interleukin-6, Interferon and Tumour Necrosis Factor$\alpha$-Release in RAW 264.7 Cells. Z. Naturforsch, 58: 395-400.

[74] Abu-Elala, NM.; Galal, MK.; AbdElsalam, RM.; Mohey-Elsaeed, O. and Ragaa, NM. (2016): Effects of Dietary Supplementation of Spirulina platensis and Garlic on the Growth Performance and Expression Levels of Immunerelated Genes in Nile tilapia (Oreochromis niloticus). J Aquac Res Development, 7: 433.

[75] Mahmoud, MMA.; El-Lamie, MMM.; Kilany, OE. And Dessouki, AA. (2017): Spirulina (Arthrospira platensis) supplementation improves growth performance, feed utilization, immune response, and relieves oxidative stress in Nile tilapia (Oreochromis niloticus) challenged with Pseudomonas fluorescens. Fish Shellfish Immunol, 5(72): 291-300.

[76] Olgerts, R.; Pavlovskis, A. and Bengt W. (1982): Pseudomonas aeruginosa toxins. Medical Microbiology, I: 97-128.

[77] Eissa, NME.; Abou El-Ghiet, EN.; Shaheen, AA. and Abbass, A. (2010): Characterization of Pseudomonas Species Isolated from Tilapia "Oreochromis niloticus" in Qaroun and Wadi-El-Rayan Lakes, Egypt. Global Veterinaria, 5 (2): 116-121. 


\section{الملخص العربى}

\section{تقييم التأثير المحفز للمناعه للسبيرولينا بلاتنسيس والمريميه فى البلطى النيلى

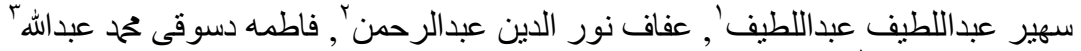

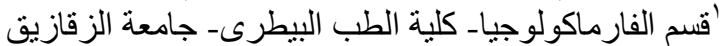

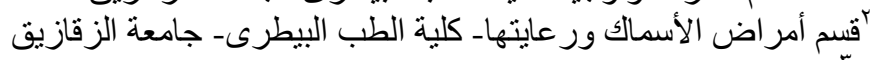

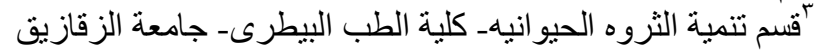

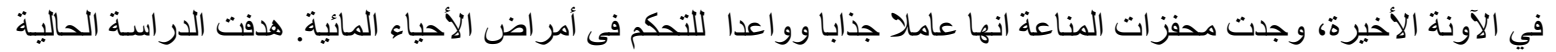

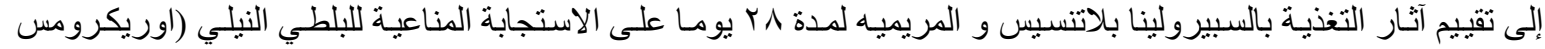

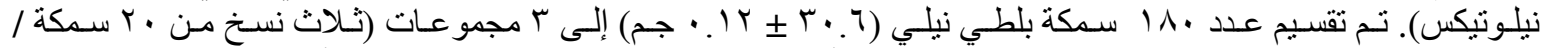

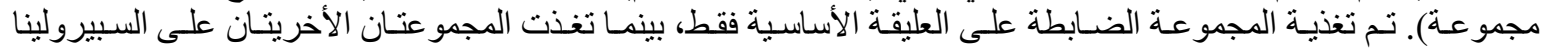

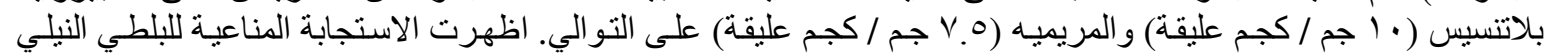

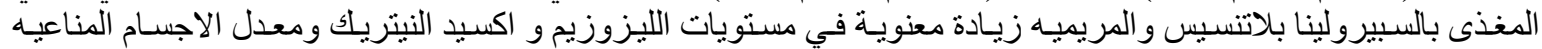

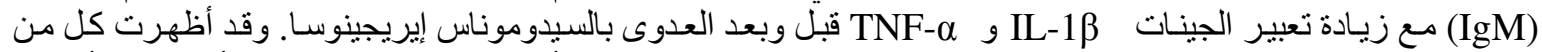

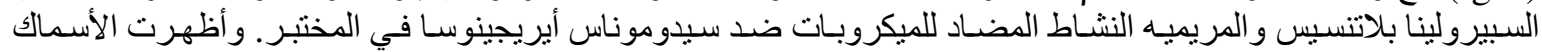

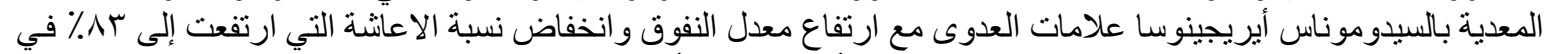

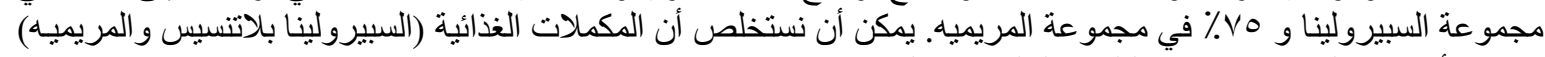
تعزز الأستجابة المناعية وتحمى البلطي النيلي ضد العدوى. 